\title{
STUDY OF FERMENTATION GROWTH KINETICS AND SURVIVAL AFTER FREEZING AND LYOPHILIZATION OF MICROORGANISMS ISOLATED FROM BRAZILIAN GRAPE SOURDOUGH
}

\author{
Krischina Singer APLEVICZ \\ Tiago da SILVA ${ }^{2}$ \\ Luiz Rodrigo Ito MORIOKA ${ }^{3}$ \\ Ernani Sebastião SANT'ANNA ${ }^{4}$ \\ Regina Coeli de Oliveira TORRES ${ }^{5}$
}

\footnotetext{
${ }^{1} \mathrm{PhD}$ in Food Sciences, Professor at the Federal Institute of Santa Catarina, aplevicz@gmail.com

${ }^{2}$ Fellow Student Federal University of Santa Catarina, tiagroalimentar@gmail.com

${ }^{3} \mathrm{PhD}$ in Food Sciences, Post- doctoral student of the Federal University of Santa Catarina, lrodrigoi@yahoo.com.br

${ }^{4} \mathrm{PhD}$ in Food Sciences, Professor at the Federal University of Santa Catarina, ernanis.santanna@ufsc.br

${ }^{5} \mathrm{PhD}$ in Food Sciences, Central Laboratory of Public Health, Florianópolis, rcotorres@gmail.com
}

Recebido em: 17/12/2014 - Aprovado em: 04/06/2015 - Disponibilizado em: 15/07/2015

\begin{abstract}
This study was developed to evaluate the influence of strains of Lactobacillus paracasei (LP1 and LP2) and Saccharomyces cerevisiae (SC1 and SC2) in fermentation and in survival during the processes of freezing and lyophilization. The microorganisms were cultivated in a discontinuous fermentation system for $15 \mathrm{~h}$ and the analyses of $\mathrm{pH}$, absorbance, dry biomass and plate counts were performed. LP1 showed the same exponential phase as LP2, and its specific speed of growth was higher and statistically different from the others $(\mathrm{P}<0.05)$. The yeasts presented growth rates higher than the LAB. However, the LAB presented higher biomass yields and lower pH values. LP2 showed the same exponential phase as LP1, its specific rate of growth was higher and statistically different from the others $(\mathrm{P}<$ 0.05). The microorganisms presented good stability before and after lyophilization, with LP2 showing lower microbial reduction.
\end{abstract}

Keywords: fermentation, kinetics, lyophilization.

\section{ESTUDO DA CINÉTICA DE FERMENTAÇÃO E SOBREVIVÊNCIA AO CONGELAMENTO E LIOFILIZAÇÃ̃O DE MICRO-ORGANISMOS ISOLADOS DO FERMENTO NATURAL DE UVA BRASILEIRA}

\begin{abstract}
RESUMO: Este estudo avaliou a influência de cepas de Lactobacillus paracasei (LP1 e LP2) e de Saccharomyces cerevisiae (SC1 e SC2) na fermentação e na sobrevivência ao congelamento e à liofilização. Os micro-organismos foram cultivados em um sistema de fermentação descontínua durante $15 \mathrm{~h}$, sendo realizadas as análises de pH, absorbância, biomassa seca e contagem em placas. LP1 teve a mesma fase exponencial que LP2, mas a sua velocidade específica de crescimento foi maior e estatisticamente diferente das demais $(\mathrm{P}<0,05)$. As leveduras apresentaram um crescimento mais rápido que as bactérias láticas. Entretanto, as bactérias láticas apresentaram maior biomassa e menor pH. LP2 obteve a mesma fase exponencial que LP1, e seu crescimento específico foi maior e estatisticamente diferentes dos demais $(\mathrm{P}<0,05)$. Os micro-organismos apresentaram uma boa estabilidade antes e após a liofilização e LP2 obteve a menor redução microbiana.

Palavras-chave: fermentação, cinética, liofilização.
\end{abstract}

\section{INTRODUCTION}

Sourdough is a mixture of flour and

water fermented by LAB and yeast
(HANSEN, 2006), which have low $\mathrm{pH}$ and high acidity. The LAB microbiota is predominant (8 log CFU/ g) and is mainly 
represented by members of the Lactobacillus genus. Yeasts are generally counted at lower levels (7 log CFU/g) and can even be absent. The yeasts mainly belong to the Saccharomyces and Candida genera. Sourdoughs can be obtained from different methods, either through spontaneous fermentation or with selected starter strains (DE VUYST, NEYSENS 2005; HAMMES et al., 2005; CORSETTI, SETTANNI, 2007).

The current renaissance of sourdough application in bread making is motivated by the beneficial effects of sourdough on flavor, texture, shelf life and nutritional properties (GÄNZLE et al., 2007). Consecutive microbial re-inoculation, often called 'backslopping', of the microorganisms from a previous batch is used to maintain the microbial flora, which is adapted and selected to the process applied (HÄGGMAN, SALOVAARA, 2008). Hence, backslopping results in the dominance of the best adapted strains (LEROY, DE VUYST, 2004). Tulha et al. (2011) have observed that the continued propagation of sourdough is designed to keep the microorganisms active.

Originally, industrial starter cultures were maintained by daily propagation. Later, they became available as frozen concentrates and dried or lyophilized preparations, produced on an industrial scale, some of them allowing direct vat inoculation (SANDINE, 1996).
The quality and shelf life of foods are often determined by the growth of microorganisms that are dependent on intrinsic factors, such as water activity and acidity, and extrinsic factors, such as temperature and oxygen (WIJTZES et al., 1995). Apart from the variations in the type of starter cultures used in the fermentation process, the fermentation regime (temperature, time, $\mathrm{pH}$, etc.) may also differ significantly, depending on the process applied (HANSEN, SCHIEBERLE, 2005).

The objective of this study was evaluate the influence of LAB of Lactobacillus paracasei (LP1 and LP2) and yeast Saccharomyces cerevisiae (SC1 and SC2) in fermentation, in surviving freezing and lyophilization, as well as their effect on sourdough preparation using the three-stage technique.

\section{MATERIALS AND METHODS}

\section{Cultivation of microorganisms}

Grape sourdough was spontaneously fermented using "Niagara rosada" grape juice as substrate, which was obtained commercially locally and previously cleaned. The strains used in this study were isolated from Brazilian grape sourdough and characterized phenotypically and genotypically as Lactobacillus paracasei (LP1 and LP2) and Saccharomyces cerevisiae (SC1 and SC2). 
Inoculates were produced from an isolated culture that was peaked monthly and activated in individual tubes containing $5 \mathrm{~mL}$ of MRS broth (Difco, Sparks, USA) at 30 ${ }^{\circ} \mathrm{C} / 16 \mathrm{~h}$ for $\mathrm{LAB}$, and malt extract broth (HiMedia, Mumbai, India) at $25{ }^{\circ} \mathrm{C} / 24 \mathrm{~h}$ for the yeasts. The final population of the inoculate was $5.45 \log \mathrm{CFU} / \mathrm{g}$ for LP1, 9.79 $\log \mathrm{CFU} / \mathrm{g}$ for LP2, $4.67 \mathrm{log} \mathrm{CFU} / \mathrm{g}$ for $\mathrm{SC} 1$ and $4.54 \log \mathrm{CFU} / \mathrm{g}$ for SC2.

The microorganisms were cultivated in a discontinuous fermentation system (model Bioflo 2000, New Brunswick Scientific, USA) containing $4.5 \mathrm{~L}$ of culture media at $100 \mathrm{rpm}$ for $15 \mathrm{~h}$.

After each culture reached the stationary stage the fermentation was centrifuged (model NT-825, Novatécnica, Piracicaba, Brazil) at $6000 \times \mathrm{g}$ for $15 \mathrm{~min}$ at 4 ${ }^{\circ} \mathrm{C}$. The supernatant was discarded and the biomass was washed twice with sterile

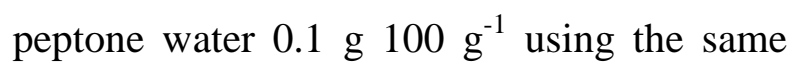
proportion of the original broth volume and re-suspended to $1 / 40$ volume of microorganisms in skimmed milk $\left(10 \% \mathrm{~m} . \mathrm{v}^{-1}\right)$ as cryoprotectant (adapted FIORENTINI et al., 2009). The solution was frozen at $-20{ }^{\circ} \mathrm{C}$ in $50 \mathrm{~mL}$ falcons using only $1 / 3$ of their capacity. The whole process was conducted under aseptic conditions.

\section{Evaluation of fermentation}

Samples were collected every 60 minutes consecutively for $15 \mathrm{~h}$ in sterile vials for analysis of $\mathrm{pH}$, absorbance, dry biomass and plate counts. The $\mathrm{pH}$ was measured by $\mathrm{pH}$ meter (model Q-400, Quimis, Diadema, Brazil) and absorbance in a spectrophotometer (model U-2010, Hitachi, Tokyo, Japan) at $660 \mathrm{~nm}$ (OD 660nm) (ANASTASSIADIS et al., 2005; EDWARD et al. 2011). The dry biomass was obtained by filtration in Durapore HV $0.45 \mu \mathrm{m}$ (Millipore) membranes and dried in an oven at $60{ }^{\circ} \mathrm{C}$ until constant weight. The result was expressed in $\mathrm{g} / \mathrm{L}$. The evaluation of growth was determined by plate counts of logarithm of the number of viable cells (log $\mathrm{CFU} / \mathrm{g})$. The LAB were grown in MRS Agar (Difco, Sparks, USA) at $30{ }^{\circ} \mathrm{C} / 48 \mathrm{~h}$ and the yeasts were grown in PDA Agar (HiMedia, Mumbai, India) with tartaric acid (10\%) at $25^{\circ} \mathrm{C} / 72 \mathrm{~h}$. Results were expressed as mean \pm standard deviation of three replicates in duplicate.

\section{Specific growth rate and duplication time}

The fermentation kinetics were carried out to verify the exponential time of each microorganism to make the largest collection of biomass. The specific growth rate, $\mu\left(\mathrm{h}^{-1}\right)$ and the doubling time, $\mathrm{t}_{\mathrm{d}}(\mathrm{h})$ of $\mathrm{LAB}$ and yeast were calculated from the growth curves of the number of viable cells (CFU/g) versus time (h).

The maximum specific growth rate was in accordance with the angular coefficient (inclination) of the linear equation of the natural logarithm of the number of colonies $\ln$ 
[N] in function of the fermentation period $t$ (h) related to the exponential growth phase, which was determined by the linear regression (RIBEIRO, HORRI, 2004).

The doubling time $\left(t_{d}\right)$ was defined by Montville (1997) and recorded according to Equation (1).

$\mathrm{t}_{\mathrm{d}}=\ln 2 / \mu$

\section{Lyophilization}

Samples of microorganisms were placed in a lyophilizer (model LT1000, Terroni, São Carlos, Brazil) for $24 \mathrm{~h}$ at 90 $\mu \mathrm{Hg}$ vacuum. The lyophilized cultures were stored at $-20^{\circ} \mathrm{C}$.

\section{Survival of the microorganisms after lyophilization}

Survival was measured by a $\log$ of the number of viable cells in colony-forming units per $\mathrm{g}(\log \mathrm{CFU} / \mathrm{g})$, before and after lyophilization. An aliquot of the culture in milk solution was withdrawn and subjected to

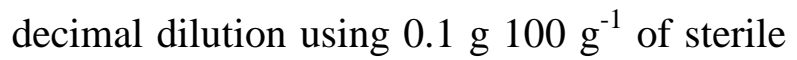
peptone water. It was then plated and incubated. The lyophilized samples were analyzed initially and after 6 months. They were, re-suspended in peptone water, diluted, plated and incubated (PALMFELDT, HAHNHÄGERDAL, 2000). Experiments were performed in triplicate in three replications.

\section{Statistical analysis}

The statistical analysis was carried out using Statistica ${ }^{\circledR}$ software version 8.0 (Statsoft Inc., Tulsa, OK, USA). The fermentation growth kinetics during $15 \mathrm{~h}$ was studied by a simple linear regression model, given by $Y=\beta_{0}+\beta_{1} X+\varepsilon$, where $X$ is the fermentation time in hours. Differences between the means were established using one-way analysis of variance (ANOVA) followed by Tukey's test. Differences at the $5 \%$ level $(\mathrm{P}<0.05)$ were considered statistically significant.

\section{RESULTS AND DISCUSSION}

\section{Fermentation growth kinetics}

The estimated equations of analysis of linear regression for $\mathrm{pH}$, absorbance at 660 $\mathrm{nm}$, dry biomass and plate counts of microorganisms studied at $15 \mathrm{~h}$ are shown in Figure 1 (A, B, C and D).

The analyses of linear regression after $15 \mathrm{~h}$ indicated that the linear and angular coefficients of SC1 and SC2 and the angular coefficient of LP1 and LP2 regarding the rate of decrease of $\mathrm{pH}$ (Figure 1A) were statistically similar $(\mathrm{P}>0.05)$. Therefore, $\mathrm{H}_{0}$ was not rejected for the $\mathrm{F}$ test at significance level of $5 \%$, where $\mathrm{H}_{0}$ indicates that angular coefficients are equal. All other contrasts showed statistical difference between treatments $(\mathrm{P}<0.05)$. In the $\mathrm{pH}$ analysis a higher coefficient of determination for the 
LAB (LP1: 0.9090; LP2: 0.9823) was observed, followed by the SC2 (0.8328) and $\mathrm{SC} 1$ yeasts $(0.6577)$.

From the results obtained for the rate of increase in absorbance at $660 \mathrm{~nm}$ during 15 $\mathrm{h}$ of fermentation (Figure 1B) it was observed that the regression coefficients of LP2/SC2 were equal. The linear coefficients were significantly different for LP1/SC2 and SC1/SC2. We observed a higher coefficient of determination in absorbance for LP2, followed by SC2; SC1 and LP1 $\left(r^{2}=0.9878\right.$; 0.9726; 0.9530; 0.8111). Corsetti et al. (2000) reported that the absorbance obtained exceed the registered maximum of 1.25 for a count of $9 \mathrm{CFU} / \mathrm{g}$ of $\mathrm{LAB}$ when cultivated at $24^{\circ} \mathrm{C}$ in MRS broth. Counts of L. plantarum varied between 9.1 and $10.6 \log \mathrm{CFU} / \mathrm{g}$ for the fermentations inoculated with the starter strains after $48 \mathrm{~h}$ of fermentation (EDWARD et al. 2011). The initial $\mathrm{pH}$ of $L$. brevis was 6.33 and at $10 \mathrm{~h}$ it was 4.98 (LEÓN et al., 2006).

The regression analysis relating to the increase of biomass during $15 \mathrm{~h}$ (Figure 1C), using $F$ test to contrast angular coefficients, indicated that LP1 and SC2 differed between themselves; they showed different rates of growth at a significance level of $5 \%$. All the other tests of comparison of angular coefficients did not show significant difference between treatments $(\mathrm{P}>$ 0.05). Regarding the linear coefficient, only SC1 and SC2 were equal. Other comparisons between the linear coefficients were significantly different $(\mathrm{P}<0.05)$. SC2 had the highest result of coefficient of determination for dry biomass of 0.9717 , followed by LP2, SC1 and LP1. The Lactobacillus fermentum strain produced $2.8 \mathrm{~g} / \mathrm{L}$ biomass compared to $2.6 \mathrm{~g} / \mathrm{L}$ for $L$. mesenteroides ssp. mesenteroides and $5.1 \mathrm{~g} / \mathrm{L}$ produced by $L$. plantarum. The L. fermentum strain obtained end counts of $11.6(\log \mathrm{CFU} / \mathrm{g})$ with $18 \mathrm{~h}$ of fermentation, while L. plantarum presented $12.2 \log \mathrm{CFU} / \mathrm{g}$. The biomass produced by Weissella paramesenteroides strains BFE7601 and BFE7608 were only 1.4 and 3.7 $\mathrm{g} / \mathrm{L}$, respectively, and the counts in freezedried residue were between 11.3 and $12.2 \mathrm{log}$ $\mathrm{CFU} / \mathrm{g}$. The fermentation time was between 8 and $14.5 \mathrm{~h}$ (EDWARD et al., 2011).

Regarding plate counts during $15 \mathrm{~h}$ (Figure 1D), regression analysis indicated that the angular and linear coefficients of SC1 and SC2 and the linear coefficient of LP1 and $\mathrm{SC} 1$ were statistically equal $(\mathrm{P}>0.05)$. Consequently, $\mathrm{H}_{0}$ was not rejected by $\mathrm{F}$ test at a significance level of 5\%. All other comparisons between angular and linear coefficients showed statistical difference between treatments $(\mathrm{P}<0.05)$. The highest coefficients of determination $\left(\mathrm{r}^{2}\right)$ for plate counts were for LP2 (0.9926) and LP1 (0.9772), followed by SC2 (0.8159) and SC1 (0.7271). León et al. (2006) reported that $L$. brevis showed a rapid growth from the beginning, with a score of $5.61 \log \mathrm{CFU} / \mathrm{g}$ 
(absorbance 0.130), in $10 \mathrm{~h}$ with $11.91 \mathrm{log}$ CFU/g (absorbance 1.180) reached in $12 \mathrm{~h}$ (the stationary phase) and decline at $21 \mathrm{~h}$. Salovaara (2004) obtained similar growth values between 7 and $8 \mathrm{~h}$ of cultivation, with 9.28 CFU/g.

The highest growth rates were for LP1 and were observed after $15 \mathrm{~h}$, with $\mathrm{pH}$ of $4.28 \pm 0.16$, absorbance of $1.793 \pm 0.15$ and $8.81 \log \mathrm{CFU} / \mathrm{g}$. Also after a period of $15 \mathrm{~h}$, LP2 showed $\mathrm{pH}$ of $4.44 \pm 0.01$, absorbance of $2.346 \pm 0.06$ and $13.23 \log \mathrm{CFU} / \mathrm{g}$. Biomass production of $3.6 \pm 0.28$ and $3.5 \pm 0.14 \mathrm{~g} / \mathrm{L}$ were observed for LP1 and LP2, respectively. After $10 \mathrm{~h}, \mathrm{SC} 1$ showed $\mathrm{pH}$ of $4.72 \pm 0.30$, while after $14 \mathrm{~h} \mathrm{SC2}$ showed $4.69 \pm 0.17$. Both yeasts presented the same biomass production of $1.6 \pm 0.00 \mathrm{~g} / \mathrm{L}$, absorbance $1.479 \pm 0.01$ and $1.456 \pm 0.01$ and plate counts of $7.68 \log \mathrm{CFU} / \mathrm{g}$ and $7.50 \mathrm{log}$ $\mathrm{CFU} / \mathrm{g}$, respectively.

The results showed that the yeasts presented growth rates higher than the LAB. However, the LAB presented higher biomass production and lower $\mathrm{pH}$ values. Starter cultures can be composed of individual strains of LAB or mixtures of LAB and yeasts. Their use ensures quality in bread making. The use of starter cultures requires prior knowledge of their biochemical characteristics and the baking potential of the microorganisms. The performance of isolated LAB has mainly been studied by characterization of the acidification properties such as $\mathrm{pH}$, total titratable acidity and lactic and acetic acids, which are produced during sourdough fermentation (COLLAR, 1996; CORSETTI et al., 1998; HAMMES, GÄNZLE, 1998).

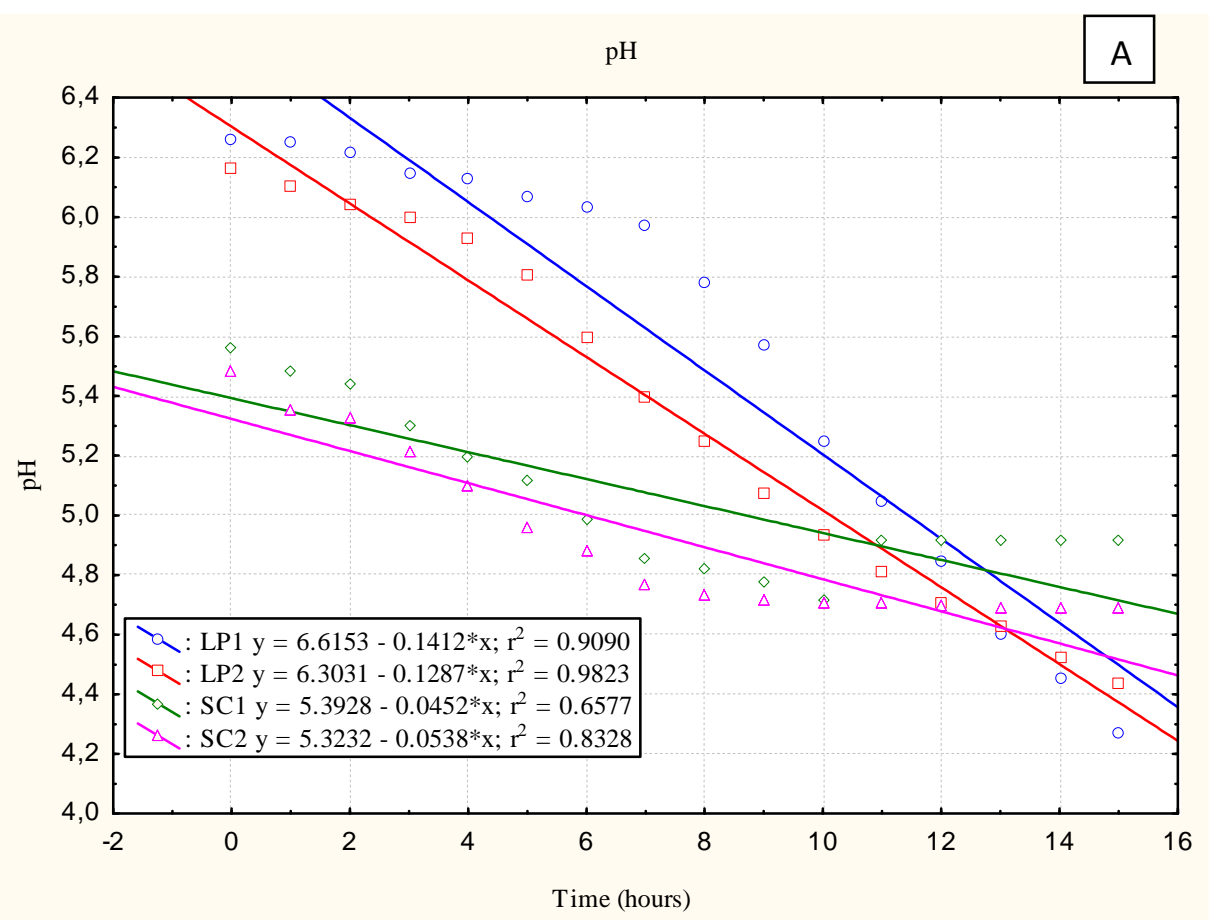



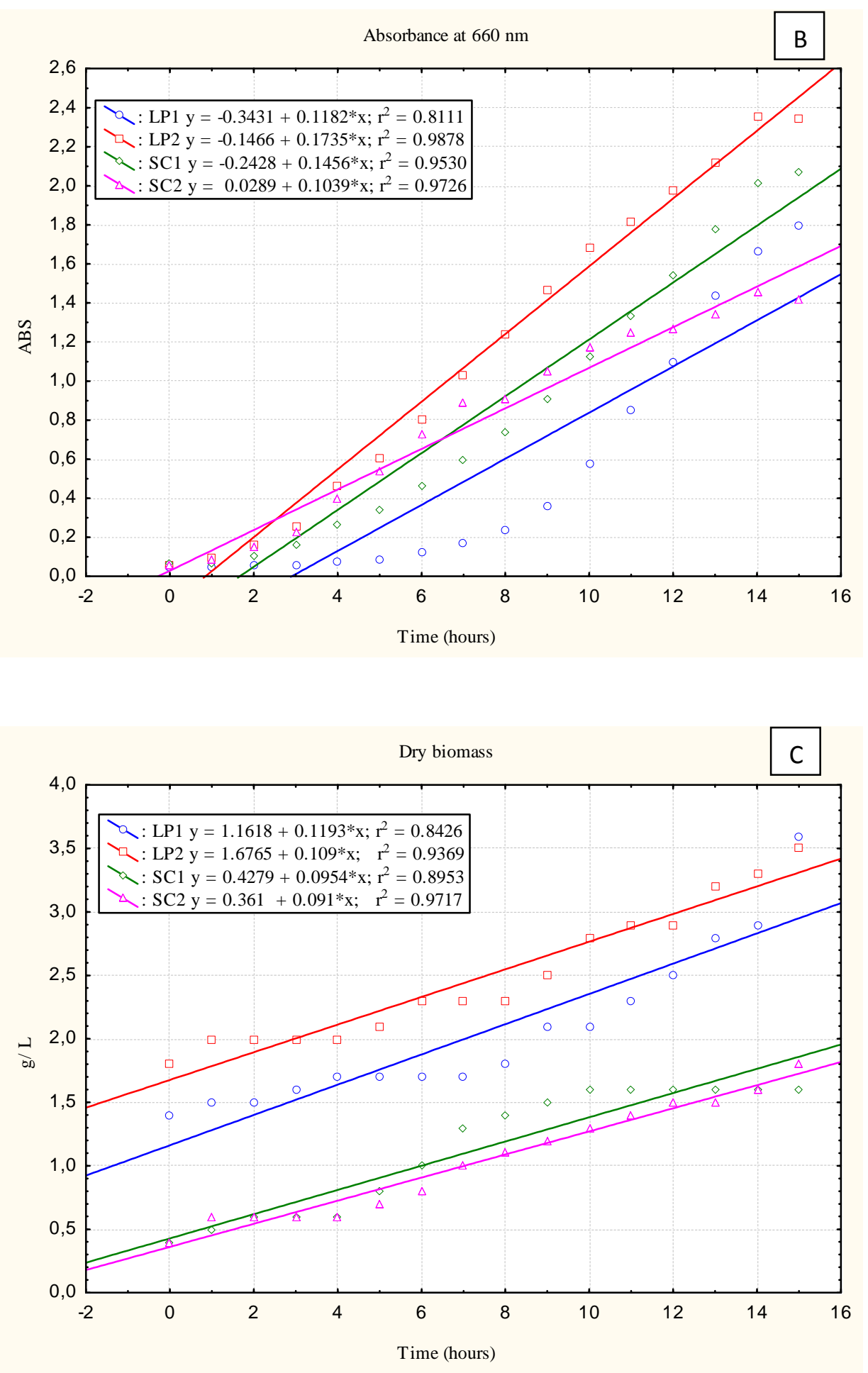


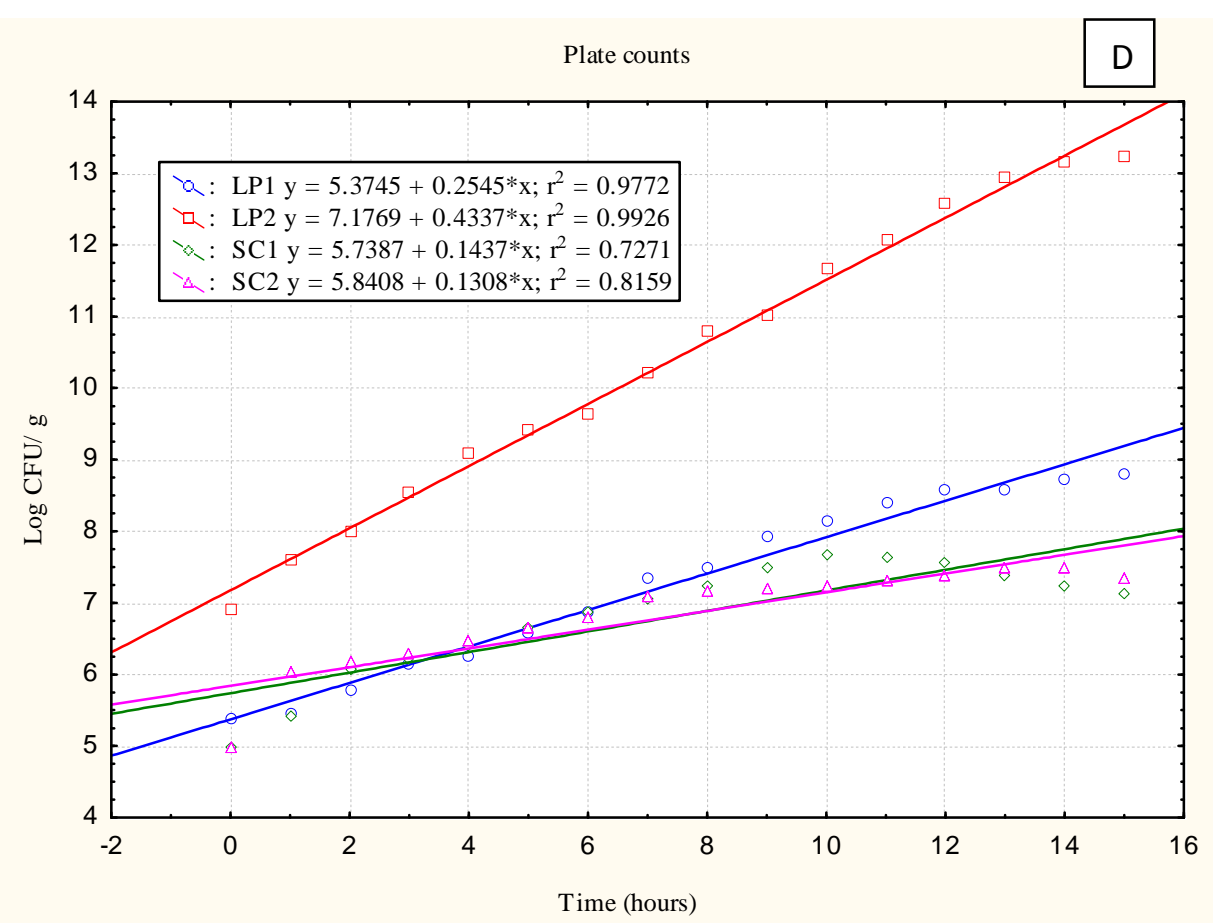

Figure 1 - Evolution of $\mathrm{pH}(\mathrm{A})$, absorbance at 660nm (B), dry biomass (C) and plate counts (D) over time

\section{Evaluation of specific growth rate doubling time of microorganisms are duplication time presented in Table 1.}

The evolution of plate counts in the exponential phase over time is illustrated in Figure 2. The specific growth rate and

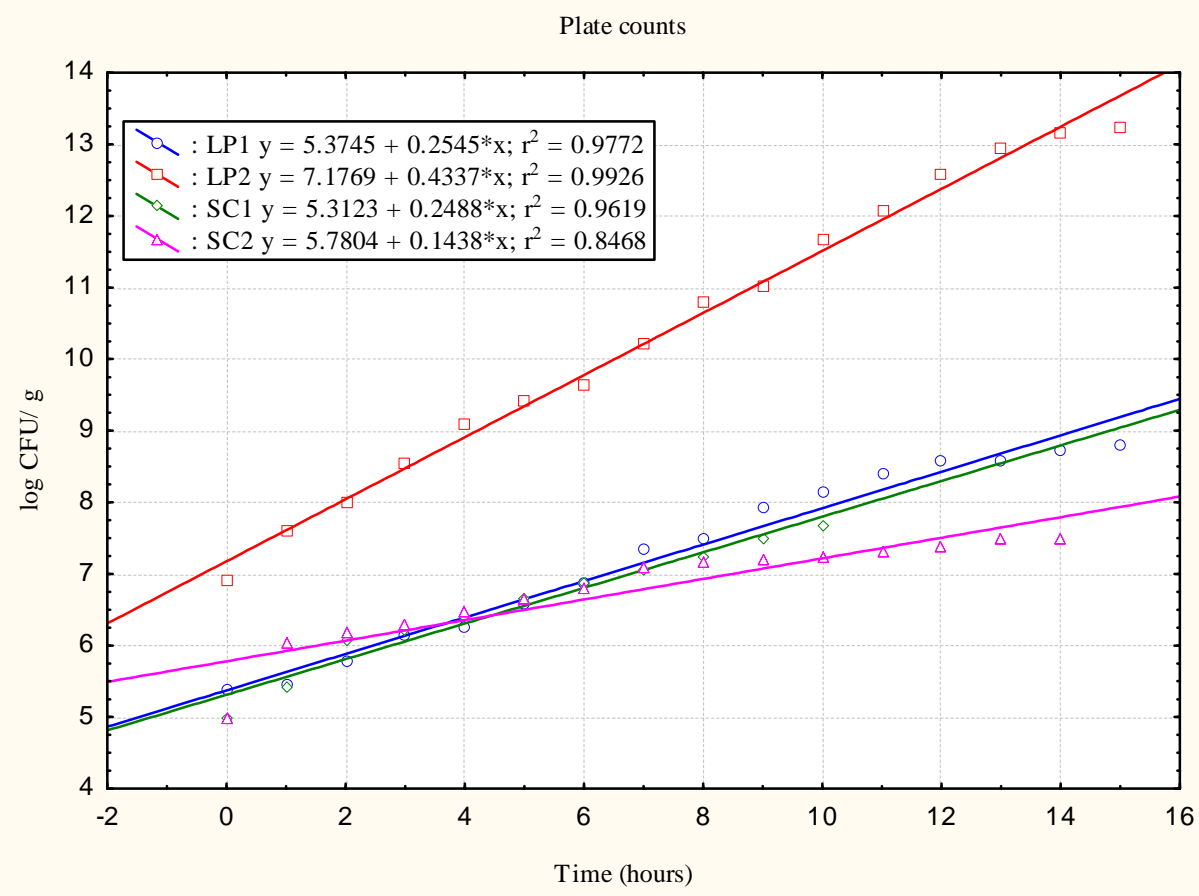

Figure 2 - Evolution of plate counts in exponential phase over time 
First order kinetic reactions can be used to describe changes in cell numbers during the exponential phase of growth. Food microbiologists generally use the doubling time $\left(t_{d}\right)$ as a kinetic constant to describe the rate of exponential growth (MONTVILLE, 1997). The length of the lag phase may vary considerably; it may be short or even be absent if the inoculum is obtained from a culture in the exponential phase of growth. It may be long if the inoculum is obtained from a rich medium and the microorganism is placed in a minimally defined medium (INGRAHAM et al., 1997).

Table 1 - Specific growth rate $(\mu)$ and doubling time $\left(t_{d}\right)$ of microorganisms

\begin{tabular}{lcc}
\hline Samples & $\mu\left(\mathrm{h}^{-1}\right)$ & $\mathrm{td}(\mathrm{h})$ \\
\hline $\mathrm{LP} 1$ & $0.586 \pm 0.00^{\mathrm{b}}$ & $1.18 \pm 0.00^{\mathrm{b}}$ \\
$\mathrm{LP} 2$ & $0.999 \pm 0.03^{\mathrm{c}}$ & $0.69 \pm 0.02^{\mathrm{a}}$ \\
$\mathrm{SC} 1$ & $0.573 \pm 0.01^{\mathrm{b}}$ & $1.20 \pm 0.02^{\mathrm{b}}$ \\
$\mathrm{SC} 2$ & $0.331 \pm 0.01^{\mathrm{a}}$ & $2.09 \pm 0.08^{\mathrm{c}}$ \\
\hline Results as mean \pm standard deviation. & ${ }^{\mathrm{a}-\mathrm{c}}$ Different \\
superscript letters between samples in the same column \\
denote significant differences (Tukey's test, P < 0.05).
\end{tabular}

The exponential phase of the LP1 culture was 0 to $15 \mathrm{~h}$. LP1 showed a specific growth rate of $0.586 \mathrm{~h}^{-1}$, corresponding to a doubling time of $1.18 \mathrm{~h}$. Despite the fact that the inoculates originated from cultures in the exponential phase, a lag phase of $1 \mathrm{~h}$ was observed for LP1.

LP2 showed the same exponential phase as LP1 but its specific growth rate was greater at $0.999 \mathrm{~h}^{-1}$ with $0.69 \mathrm{~h}$ of doubling time, which was statistically different from the others $(\mathrm{P}<0.05)$. In broth with LP2, the value of $\mathrm{r}^{2}$ was 0.9926 , meaning that the adjustment of regression explains $99.26 \%$ of the total variance of $\mathrm{Y}$, but only $0.74 \%$ for the residual variation (error), which is considered a good fit.

Shin et al. (2000) reported that the mean doubling time of Bifidobacterium spp. grown in skimmed milk was $3.95 \mathrm{~h}$. Lactobacillus sp. (LB - 12) showed higher specific growth rate and thus less doubling time ( $\left.\mu: 0.5480 \mathrm{~h}^{-1} ; \mathrm{T}_{\mathrm{d}}: 1.2 \mathrm{~h}\right)$. Lactobacillus acidophilus presented a specific growth rate of $0.4930 \mathrm{~h}^{-1}$ and $\mathrm{T}_{\mathrm{d}}$ of $1.4 \mathrm{~h}$ (Brizuela et al., 2001). Adamberg et al. (2003) found that during the decrease of $\mathrm{pH}$ from 6.2 to 5.8 the specific growth rate of $L$. bulgaricus was 
almost constant $\left(1.15 \mathrm{~h}^{-1}\right)$. L. acidophilus and L. paracasei had the lowest specific growth rates $\left(0.5\right.$ and $\left.0.3 \mathrm{~h}^{-1}\right)$, respectively.

In the broth with $\mathrm{SC} 1$ yeast, the exponential phase was lower (only $10 \mathrm{~h}$ ) with $0.573 \mathrm{~h}^{-1}$ of specific growth rate and $1.20 \mathrm{~h}$ of doubling time. The regression coefficients for plate counts in the exponential phase of LP1 and $\mathrm{SC} 1$ were equal $(\mathrm{P}>0.05)$. All other angular and linear coefficients were significantly different.

In the broth with $\mathrm{SC} 2$, the culture remained in the exponential phase for $14 \mathrm{~h}(0$ to $14 \mathrm{~h}$ ), time that was used to estimate the linear regression equation. The specific growth rate was $0.331 \mathrm{~h}^{-1}$, with the largest doubling time of $2.09 \mathrm{~h}$, which was statistically different from the others $(\mathrm{P}<$ 0.05). The specific growth rate is a key control parameter in the industrial production of baker's yeast (VAN HOEK et al., 1998).

\section{Survival in relation to freezing and lyophilization}

Frozen LP2 and LP1 presented similar results, $11.81 \mathrm{log}$ and $11.28 \mathrm{CFU} / \mathrm{g}$, respectively, considering a reduction of 0.53 $\log$ cycles. The highest index of survival after lyophilization was for LP2, which presented $1.65 \mathrm{log}$ cycles more than LP1. Similar values to frozen LP1 and lyophilized LP2 were found, with $11.25 \log \mathrm{CFU} / \mathrm{g}$. These results are shown in Figure 3.

In relation to the yeasts, it is worth stating that before lyophilization SC1 presented $9.77 \log \mathrm{CFU} / \mathrm{g}$, while $\mathrm{SC} 2$ presented $8.91 \log \mathrm{CFU} / \mathrm{g}$, representing a reduction of $0.86 \mathrm{log}$ cycles. The greatest index survival of the lyophilized samples was for $\mathrm{SC} 1$, with $8.30 \log \mathrm{CFU} / \mathrm{g}$, while $\mathrm{SC} 2$ presented $7.5 \log$ CFU/g. During 6 months of storage a small reduction in the number of cells was observed. The results showed that the microorganisms in the study presented good stability, both before and after lyophilization, and that LP2 showed the lowest microbial reduction. Fiorentini et al. (2009) reported that cultures of Staphylococcus xylosus strains stored for 1 and 6 months at $-20{ }^{\circ} \mathrm{C}$ presented good stability using the freeze-drying process. A small decrease in the number of cells was observed during storage, which was probably due to the positive effect of storage conditions and also the cryoprotectant that was used (skimmed milk). Desirable storage conditions for freeze-dried starters are freezing temperatures below $-15{ }^{\circ} \mathrm{C}$, and the absence of oxygen and humidity. Under these conditions, the optimal activity of the starter culture will be guaranteed for eight months (BUCKENHÜSKES, 1993). According to Carvalho et al. (2004), skimmed milk is able to prevent cellular damage by stabilizing the cell membrane and providing a protective coating for the cells. Zhao and Zhang (2005) reported that when the bacterial cells of $L$. brevis and Oenococcus oeni were frozen more quickly $\left(-65^{\circ} \mathrm{C}\right)$ rather than slowly $\left(-20^{\circ} \mathrm{C}\right)$, 
both showed increased viability after freeze-

drying.

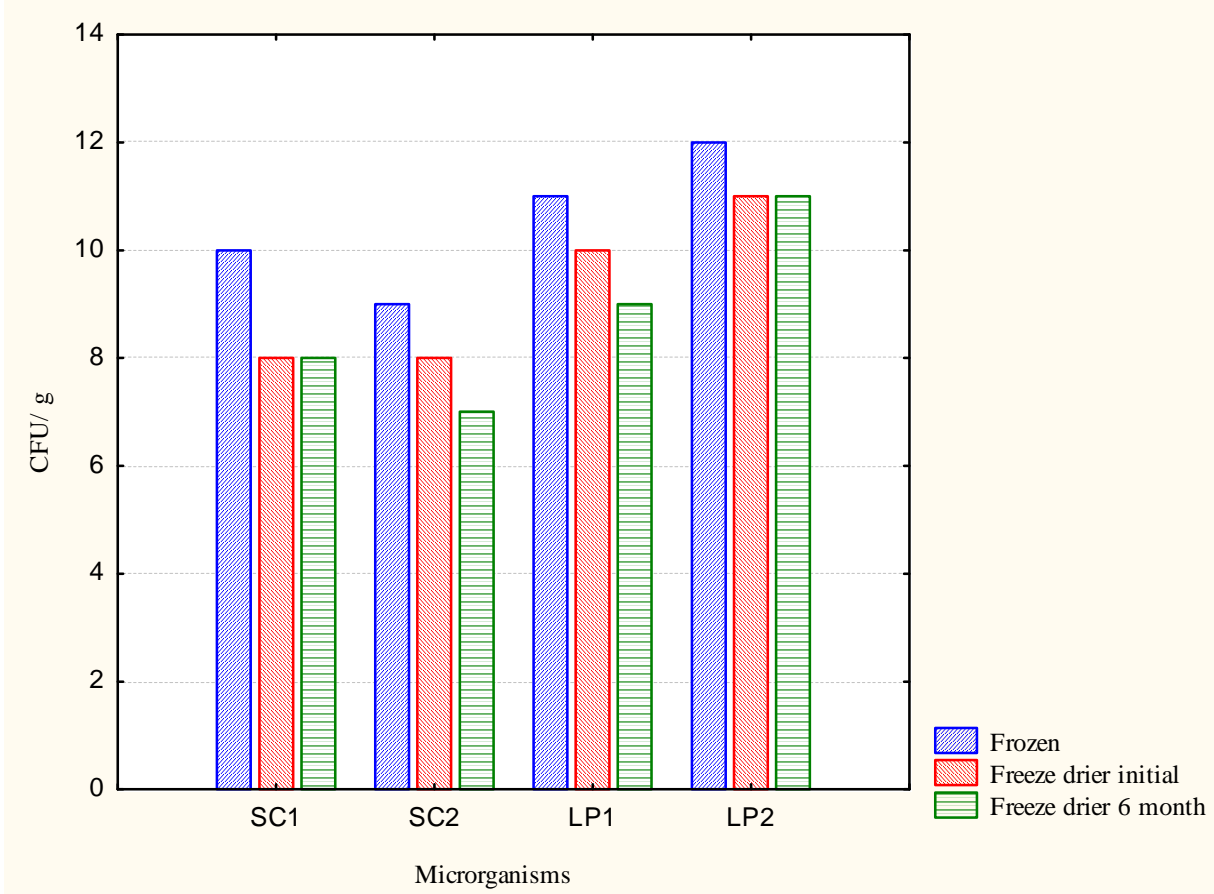

Figure 3 - Survival of frozen and lyophilized microorganisms in log CFU/g

\section{CONCLUSION}

The results of this study showed that the yeasts presented growth rates higher than the LAB. However, the LAB presented higher biomass yields and lower $\mathrm{pH}$ values.

LP2 showed the same exponential phase as LP1, its specific rate of growth was higher and statistically different from the others $(\mathrm{P}<0.05)$. SC2 showed the lowest specific growth rate $(\mathrm{P}<0.05)$, different from LP2 and SC1. The microorganisms in this study presented good stability, before and after lyophilization, with LP2 showing the lowest microbial reduction.

\section{ACKNOWLEDGMENTS}

The authors thank to the Conselho Nacional de Desenvolvimento Científico e Tecnológico $(\mathrm{CNPq})$, for their financial support.

\section{REFERENCES}

ADAMBERG, K.; KASKA, S.; PAALMEA, T.L.T. The effect of temperature and $\mathrm{pH}$ on the growth of lactic acid bacteria: a $\mathrm{pH}$ auxostat study. International Journal of Food Microbiology, v.85, p.171-183, 2003.

ANASTASSIADIS, S.; AIVASIDIS, A.; WANDREY, C.; REHM, H.J. Process 280 
optimization of continuous gluconic acid fermentation by isolated yeast-like strains of Aureobasidium pullulans. Biotechnology and Bioengineering, v. 9, p. 494-501, 2005.

BRIZUELA, M. A.; SERRANO, P.; PÉREZ, Y. Studies on probiotics properties of two Lactobacillus strains. Brazilian Archives Biology Technology, v. 44, p. 95-99, 2001.

BUCKENHÜSKES, H.J. Selection criteria for lactic acid bacteria to be used as starter cultures for various food commodities. FEMS Microbiology, v. 12, p. 253-272, 1993.

CARVALHO, A.S.; SILVA, J.; HO, P.; TEIXEIRA, P.; MALCATA, F.X.; GIBBS, P. Relevant factors for the preparation of freezedried lactic acid bacteria. International Dairy Journal, v. 14, p. 835-847, 2004.

COLLAR, C. Biochemical and technological assessment of the metabolism of pure and mixed cultures of yeast and lactic acid bacteria in breadmaking applications. Food Science and Technology International, v. 2, p. 349-367, 1996.

CORSETTI, A.; GOBBETTI, M.; BALESTRIERI, F.; PAOLETTI, F.; RUSSI, L.; ROSSI, J. Sourdough lactic acid bacteria effects on bread firmness and staling. Journal of Food Science, v. 6, p. 347-351,1998.
CORSETTI, A.; GOBETTI, M.; DE MARCO, B.; BALESTRIERI, F.; RUSSI, L.; ROSSI, I. Combined effect of sourdough lactic acid bacteria and additives on bread firmness and staling. Journal Agricuture Food Chemistry, v. 48, p. 3044-3051, 2000. CORSETTI, A.; SETTANNI, L. Lactobacilli in sourdough fermentation. Food Research International, v. 40, p. 539-558. 2007.

DE VUYST, L.; NEYSENS, P. The sourdough microflora: biodiversity and metabolic interactions. Trends Food Science Technology, v. 16, p. 43-56, 2005.

EDWARD, V.A.; HUCH, M.; DORTU, C.; THONART, P.; EGOUNLETY, M.; VAN ZYL, P.J.; SINGH, S.; HOLZAPFEL, W. H.; FRANZ, C.M.A.P. Biomass production and small-scale testing of freeze-dried lactic acid bacteria starter strains for cassava fermentations. Food Control, v. 22, p. 389395, 2011.

FIORENTINI, A.M.; SAWITZKI, M.C.; BERTOL, T.M.; SANT'ANNA, E.S. Viability of Staphylococcus xylosus isolated from artisanal sausages for application as starter cultures in meat products. Brazilian Journal of Microbiology, v. 40, p.129-133, 2009.

GÄNZLE, M.G.; VERMEULEN, N.; VOGEL, R.F. Carbohydrate, peptide and lipid 
metabolism of lactic acid bacteria in sourdough. Food Microbiology, v. 24, p.128138, 2007.

HÄGGMAN, M.; SALOVAARA, H. Microbial re-inoculation reveals differences in the leavening power of sourdough yeast strains. Lebensm-Wiss Technology, v. 4, p.148-154, 2008.

HAMMES, W.P.; BRANDT, M.J.; FRANCIS, K.L.; ROSENHEIM, J.; SEITTER, M.F.H.; VOGELMANN, S.A. Microbial ecology of cereal fermentations. Trends in Food Science and Technology, v. 16, p. 4-11, 2005.

HAMMES, W.P.; GÄNZLE, M.G. Sourdough breads and related products. In: Woods BJB Microbiology of Fermented Foods, London: Blackie Academic/ Professional, 1998. p. 199-216.

HANSEN, A.; SCHIEBERLE, P. Generation of aroma compounds during sourdough fermentation: applied and fundamental aspects. Trends in Food Science Technology, v. 16, p. 85-94, 2005.

HANSEN, A. Sourdough bread. In: HUI, Y.H.; SHERKA, F. Handbook of food science, technology and engineering, 4 ed. Taylor and Francis Group, LLC, 2006, p.183210.
INGRAHAM， J.L.; MAALØE， O.; NEIDHARDT, F.C. Microbial growth. IN: PERRY, J.J.; STALEY, J.T. Microbiology: dynamics and diversity, Sauders College Publishing, 1997. p. 136-157.

LEÓN, A.M.; MONTOYA, O.I.; MOTATO, K.E.; GRANDA， D.M.; CARO， C.A.; RESTREPO, J.M.; ECHEVERRI, S.; VALENCIA，J.; QUINCHÍA，L. Bacterias ácido lácticas silvestres colombianas presentan propiedades adecuadas para la fabricación de masa ácida. Revista de la Faculdade de Química Farmaceutica, v. 13, p. 26-35, 2006.

LEROY, F.; DE VUYST, L. Functional lactic acid bacteria starter cultures for the food fermentation industry. Trends in Food Science and Technology, v. 15, p. 67-78, 2004.

MONTVILLE, T.J. Principles which influence microbial growth, survival and death in foods. In: DOYLE, M.P.; BEUCHAT, L.R.; MONTVILLE, T.J. Food microbiology: fundamentals and frontiers. Washington, DC, ASM, 1997. p. 13-29.

PALMFELDT, J.; HAHN-HÄGERDAL, B. Influence of culture $\mathrm{pH}$ on survival of Lactobacillus reuteri subjected to freeze- 
drying. International Journal of Food

Microbiology, v. 55, p. 235-238, 2000.

RIBEIRO, C.A.F.; HORII, J. Negative $\mathrm{H}_{2} \mathrm{~S}$ character and flocculation as yeast strain markers for inoculum recovery. Science Agriculture, v. 61, p. 292-297, 2004.

SALOVAARA, H. Lactic acid bacteria in cereal-based products. In: SALMINEN, S.; VON WRIGHT, A.; OUWEHAND, A. Lactic acid bacteria, microbiology and functional aspects, New York, Marcel Dekker, 2004. p 115-135.

SANDINE, W. E. Commercial production of dairy starter cultures. In: COGAN, T.M.; ACCOLAS, J.P. Dairy starters culture, New York, J.P. VCH, 1996. p 101-129.

SHIN, H.S.; LEE, J.H.; PESTKA, J.J.; USTUNOL, Z. Growth and viability of commercial Bifidobacterium spp in skim milk containing oligosaccharides and inulin. Journal of Food Science, v. 65, p. 884-887, 2000.

TULHA, J.; CARVALHO, J.; ARMADA, R.; FARIA-OLIVEIRA， F.; LUCAS， C.; PAIS, C.; ALMEIDA, J.; FERREIRA, C. Yeast, the man's best friend. In: INTECH Open Acecss Publisher, 2011. p.255-278.
VAN HOEK, P.; VAN DIJKEN, J.P.; PRONK, J.T. Effect of specific growth rate on fermentative capacity of baker's yeast. Applied and Environmental Microbiology, v. 64, p. 4226-4233, 1998.

WIJTZES, T.; DE WIT, J.C.; IN'T VELD, J.H.; VAN'TRIET, K.; ZWIETERING, M.H. Modelling bacterial growth of Lactobacillus curvatus as a function of acidity and temperature. Applied and Enviromental Microbiology, v. 61, p. 2533-2539, 1995.

ZHAO, G.; ZHANG, G. Effect of protective agents, freezing temperature, rehydration media on viability of malolactic bacteria subjected to freeze-drying. Journal of Applied Microbiology, v. 99, p. 333-338, 2005. 